\title{
Review of Women and Society in Saudi Arabia
}

\author{
Yahya Al Alhareth", Yasra Al Alhareth, Ibtisam Al Dighrir \\ General Administration of Education in Najran Region, Ministry of Education, Riyadh, Kingdom of Saudi Arabia \\ *Corresponding author: alhareth_y@yahoo.com
}

Received December 01, 2014; Revised January 22, 2015; Accepted February 01, 2015

\begin{abstract}
Saudi society is a unique mix between religion and culture, which poses difficulties for the government over education for women. The position of women in this society is complicated and they have to face a lot of barriers to get an education as they live under male authority all the time. Thereby, this paper will review the literature on women and society in Saudi Arabia and its relation to their educational achievement, considering several different aspects including: Feminist theory, Islamic feminism in Saudi society, the status of women in Saudi society and the Holy Book of the Muslims (Qur'an) as well as their comparison in both.
\end{abstract}

Keywords: Feminist theory, Islamic feminism, Saudi society, women's situation

Cite This Article: Yahya Al Alhareth, Yasra Al Alhareth, and Ibtisam Al Dighrir, "Review of Women and Society in Saudi Arabia.” American Journal of Educational Research, vol. 3, no. 2 (2015): 121-125. doi: 10.12691/education-3-2-3.

\section{Introduction}

Saudi Arabia is a socially and religiously conservative country [24]. Its has a high cultural homogeneity based on tribal and Islamic affiliations and therefore has a unique and complex culture. Hence it is difficult to differentiate between Islamic principles and Arabic customs [2]. Some customs, such as the belief that women should not drive cars or practise Law or Engineering are not from Islamic law but have become entrenched in the culture [16]. Women's function in wider society is limited and Saudi Arabia has one of the lowest participation of women in the workplace, particularly from graduates. Yet, this is needed for the country to achieve progress [ibid]. Therefore, the government faces great challenges if it is to achieve its goal of development and fundamental changes in the way society is conducted are needed.

\section{Feminist Theory}

Feminism is a belief in social, economic as well as political equality of the two genders [17]. It recognises and criticises male supremacy while making efforts to change it. According to reference [17], this theory was born out of the movement that seeks to empower women all over the world. It focuses on gender inequality through women's social roles and experiences, social relations with males and also the promotion of women's rights [6]. Feminism seeks to demonstrate the role as well as the importance of women in society, to reveal that women in the past have been subordinates to their male counterparts, and to create gender equality. Feminists generally fight for gender equality "and argue that women should have an equal share in society's opportunities" as well as other resources that are scarce [17-21].
In principle, the philosophical understanding of the feminist theory explicates the world view of gender inequality [31]. In this regard, the theory explains the social roles of women in society including their feminist politics and experiences in diverse field discourses [9]. The principal relevance of the feminist theory is to define and analyse the critical possibilities affiliated to gender inequality [31]. Feminism asserts that the position of the woman in society is determined by institutional and social factors, in addition, there is ample evidence demonstrating that women have been continuously treated as inferior citizens [13]. As a mode of analysis, feminism is grounded in the link between the social institutions which influence the daily life of individuals and in a desire for social change. As a theory, feminism is both scientific and political. According to reference [13], feminist scholars are identified by their political interest in protesting against women's oppression and view their scholarly work as a contribution to comprehensive understanding of why and how liberation of women should be achieved.

It is important to note that feminism has no universally accepted or single definition. An analysis of feminism demonstrates that the theory is diverse in its definitions [17]. They include a description of the present situation or issue, an explanation of its roots, a review of the positive and negative aspects of the current issue, and proposals as well as strategies to produce social change in the pursuit of the declared goals and values [ibid].

In the recent past, the government has developed campaigns against gender segregation with the major stakeholders endeavouring to ensure change in the education processes within the Saudi political system and promoting equality by institutionalising more female learning institutions to enhance the number of Saudi women reaching higher education [23]. Importantly, the scrutiny on women's rights to bring about gender equality, particularly in education and leadership, defines the value- 
free direction within the political systems, not only in Saudi Arabia, but also in global political systems [26]. The processes involved in mitigating this sexual objectification and stereotyping directed against women in Saudi society with regard to education achievement include education equity by opening more institutions of higher learning for women, mainstreaming the school curricula for girls' institutions of learning and incorporating subjects and career fields that do not discriminate against the interaction between the males and females in this society [16]. Transitions from social and humanity fields to technology fields are including incorporation of ICT in the girls' curriculum which is the major effort. Essentially, this incorporation will foster the use of ICT to engender e-learning in such schools [25].

Feminist strategies concerning technology generally involve looking for non-threatening ways that can be used to enable women enhance their technical competence so they rely less on men. These efforts are however faced by a general problem which makes achievement of the intended goals a challenge. The main problem is that predicting the effects of new technologies is not always possible and by the time negative consequences become apparent, the technology's artifactual form as well as social interests that characterise it usually have become so embedded that they present a major barrier to change [31]. Feminists therefore argue that there is a need for strategies to be developed to mediate the process of designing new technologies as well as the use of these technologies. This study draws from this notion and assumes that the use of e-learning can help Saudi women to achieve their educational goals but their ability to access and use it freely should firstly be understood.

\subsection{Islamic Feminism}

Islamic feminism attempts to work within the values of Islam, not against them, by offering social benefits in a culturally satisfactory and sustainable way to families through enhanced opportunities for daughters, sisters, wives and mothers [7]. Applying feminism in a Muslim society can however be challenging. Reference [22] explains that feminism in Islamic societies is often viewed as a secular and Western ideology or 'an alien' assault to the Islamic religion and is often not supported. Reference [22] also notes that achieving equality in the family is a major challenge for Muslim feminists. Reference [1] explains that though some equality has been achieved in the public domain for many countries, gender inequality in families is still very common and sustained by statebacked laws which are based on Islamic beliefs. This might affect the achievement of the main goal of this study, which is to enhance women's ability to access and use e-learning freely. Gender inequality might hinder some families from allowing the womenfolk to take online courses because of the traditional belief that the place of the woman is at home and not 'out there' as explained by reference [29].

The ideology of feminism as an attempt to empower women globally following the acknowledgment and critique of male dominion as well as the efforts to bring change to this norm, is the foundation of Islamic feminism, which entails definition of the roles of an Islamic woman [18]. Principally, it is a movement that requires women's rights support with a focus on social justice and gender equality from an Islamic focal point [20]. In this regard, gender manipulation in terms of dressing, religious practices, politics and public life, which directly affects education achievement in the Muslim fraternity are considered for transition. Although the concern is mainly due to references to feminism within an Islamic construct, the utility of secular and non-Islamic feminism discourses incorporated is shown from a global feminist approach to ensure change in the Middle-Eastern world, Saudi Arabia included [15].

The political and social constructs embraced by Arabian countries such as Saudi Arabia are established within the dominion of male bigots and advocacy of women's leadership is not common place [ibid]. Under the current transition plans, restructuring of the education system, which is the pillar of knowledge, achievement and equity, is the main agenda in which females are provided with tailored education curricula, not only to suit women in their social and biological functional life, but also to develop them in diverse subject areas such as architecture, medicine, engineering and other technology-oriented fields [20].

The expansion of the knowledge base for Muslim women is geared by the feminist paradigm and mitigation of menial superiority complex in order to perpetuate naturalisation and recuperate gender equality as the core idea in the Islamic being [23]. A better understanding of the Islamic feminism paradigm is provided by the force of Muslim women who explain their educational needs beyond the passive common knowledge, but also by the engagement of religious practices such as Ijtihad (Rethinking Islam) without the salience rooted in the thinking and activism of their gender [18]. The manner brought by education limitations has so far surpassed considering the increased awareness of the importance of knowledge and skills garnered via education achievement, and the willingness to implement reforms within the education system delivery processes.

\section{Saudi Society}

Saudi society is built around tribal and Islamic affiliations [24] and it is difficult to differentiate between Islamic laws and Arabic traditional norms [2]. Major cities are generally less conservative than the remote areas and smaller towns and cities, though Riyadh, the capital and centre of Wahabism in the middle of the country, is seen to be more conservative than the second city, the coastal port of Jeddah in the West, which is more cosmopolitan [8]. Saudi citizens embrace the cultural and religious attributes of society in totality while the norms for public behaviour are highly regarded as conservative.

\subsection{The Status of Women in Saudi Society}

The position of women in Saudi society, especially in the public domain, is complicated [15]. The concept of male guardianship has been, and still is, one of the strong norms for Islamic women in Saudi Arabia [16]. This phenomenon has impacted on women taking up higher education and in particular women seeking education from international countries. Every woman is entitled to a male guardian, regardless of her age, by law. Politically, women 
have not been allowed to participate in any form of elections [ibid]. Recently, the king is pledging to allow women candidates to run for seats in the consultative assembly in the local elections and they will be allowed to vote [4].

The power imbalance between men and women in Saudi Arabia is not specifically stated in the laws of the country, but rather, is embedded in the social and government structures and practices [12]. Women lack access to the justice system and thus rely on their male counterparts to represent them. Such imbalance also affects their education since it is difficult for women to voice any concerns that they may have about the existing education system. This practice implies that women's ability to be and do whatever they want is limited, which must be improved. Another important area that needs improvement is the overall freedom of women in Saudi Arabia since current limitations mean that they are unable to travel beyond their home, hence their access to education opportunities is limited. This is another requirement of women's capability which needs to be focused on and should not be ignored.

In addition, the extent to which women participate in decisions relating to their own marriage is restricted by the family and male counterparts [12]. This indicates that Saudi women suffer from the exclusion from participating and playing vital roles in their society and the deprivation from getting their rights. In this regard, reinforcing women's power is required to enhance their ability to be a valuable person in their society by doing things that are important to them and live as they want. As these practices develop from the nature of Saudi society with participation from government policies, according to reference [30, p. 15], they fall under active exclusion "done by the government" and passive exclusion "result from a set of circumstances", the conservative and tribal society culture in this study. The women in Saudi Arabia lack equal access to employment and economic opportunities, on top of what the scope for women to manage their own wealth is limited by social and religious factors [12]. As a result, women are not in a position to take up education opportunities. Even methods such as elearning, which as a new form of delivery could open up opportunities for women to engage with education more freely, require substantial investment from the leaner.

The Sharia laws, as well as the tribal culture, define the gender-based roles within Saudi society [20]. These cultural aspects, particularly the tribal cultural practices, have helped shaping the position of women in society and subjugating women to gender segregation in diverse aspects of society. From a broader perspective, approximately $80 \%$ of women in Saudi society, as depicted by a government poll in 2006, are opposed to the practices of women driving or working in the same environment as men [ibid]. This shows that the majority of women are against the reforms which might release them from their often perceived suppression [28]. However, there are other groups of women, who live in the main cities e.g. Riyadh, Jeddah and in the Eastern region, who have got a high education degree, probably obtained from abroad, and who are not happy with the current status of women in society. They are highly motivated to enhance their situation so they try from time to time to put pressure on the government to change and improve their status within the community by calling women all over the country to drive cars in spite of the government and society not allowing them to do so. This shows that some changes are happening within the Saudi women community which the government needs to be ready to face by taking some decisions in favour of women as King Abdullah did when allowing 30 women to take a place in the Shura Council (called Majlis Al-Shura) [5]. This exercise of capability should be improved as it would lead women to moving forward towards being treated as humans in their society.

Notably, women make up only $21 \%$ of the Saudi workforce [28]. With the adoption of the current changes to transform male dominion, allow more equitable resource allocation between the two genders and greater gender parity, along with increased uptake of higher education by women, Saudi Arabia is considered to be one of the Islamic countries achieving the highest economic development [32]. However, it is clear that women in Saudi Arabia still have few or no political and/or social rights.

The position of women in Saudi Arabia also differs from that of other Islamic communities demonstrating that the more conservative society has evolved. Taking as an example Indonesia, in comparison, Saudi women have fewer rights and freedom. In Indonesia, there is no gender segregation in relation to education and public work as is the case in Saudi Arabia [19]. Women are allowed to enjoy higher education with their male counterparts. Driving is not an issue for Indonesian women [14]. More so, travelling for higher education or for international employment does not call for the company of a male guardian. Interestingly, the Saudi government and its society see this diversity as a moral decline of the Muslims in the Indonesian community [ibid]. This points to the likelihood of changes in such practices being slow to come to Saudi Arabia, if indeed they happen at all. As a result, such methods as e-learning will provide opportunities which will appeal to both genders and satisfy the expectations of society for the foreseeable future.

\subsection{The Status of Women in the Holy Book of Muslim (Qur'an)}

The Holy Book of the Islamic religion, the Qur'an, has provided various teachings defining the place of women in Muslim society [10]. At some point, the Qur'an defines males as superior to women by saying that, "Men have authority over women because God has made the one superior to the other...” (Holy Qur'an, 4:34) It also shows men a degree above women in many ways by saying that, "...Of course, men are a degree above them in status..." (Holy Qur'an, 2:228). The Qur'an give each men a double share of the inheritance over what each woman gets by saying that, "The share of the male shall be twice that of a female" (Holy Qur'an, 4:11). It explains the roles of both males and females based on their gender, making that of males to dominate over females [10]. For instance, the Qur'an has provisions in many chapters regarding the virtues of a modest woman [11] and has appealed against female infanticide, shunning abortion as inhumane [10].

Additionally, according to the Qur'an, there must be education equity with men and women receiving 
education in the same way [11]. Moreover, it explains the way women should be treated by their husbands, defining extension of kindness from men to women [23] by saying that, "...Wives have the same rights as the husbands have on them in accordance with the generally known principles” (Holy Qur'an, 2:228). Specifically, the Holy Book describes the conduct of men explaining the character of an ideal believer in terms of best practices and deeds directed to the wives. It is the understanding of the Qur'an that has been manipulated to suit the needs of men to suppress women by exercising their dominance [ibid].

Equality has all its facets delineated in the Holy Book of Islam, which views humankind as made of equals in the eyes of Allah, without any distinction [10]. Moreover, it is plain that the equality between women and men is brought about by the mere essence of righteous deeds, which uphold the moral standing of one human being over the other and not gender disparities [ibid] by saying that, "...the most noble of you in the sight of Allah is the most righteous of you...” (Holy Qur'an, 49:13). Enormous respect, therefore, has been accorded to the righteous Muslim men and women described in the Qur'an, who are pious, to demarcate right from wrong in the eyes of Allah [10]. The role of women from the Islamic teachings, in the Qur'an, has historically been to serve the religious communities in diverse capacities, as leaders, health care providers and teachers as well as in the military. In interpretation, the Islamic belief explains equality, not to place men and women at the same level of dominance, but to explain their differences in terms of physical and emotional strengths to recognise their roles in their society [ibid]. Based on the above discussion, the Holy Book (Qur'an) offers capabilities that benefit women such as their right to make their own decision about which things are suitable for them in Islamic societies, but the structure of these societies gives men the power to control these capabilities and change them to serve their needs.

\subsection{A Comparison between Women Place in Saudi Society and the Holy Book (Qur'an)}

The concept of inferiority, which is projected onto Muslim women, is only an unconventional behavioural reduction resulting from uncouth interpretation of the Qur'an [27]. There are many indications in the Qur'an that orient women towards many spheres of life, disregarding the gender ideology, by elevating the status of Islamic women [20]. The Muslim society in Saudi Arabia, and the world at large, belittles the achievements of Islamic women by exercising norms that ensure male dominion over females in general practices, including in education [27]. The reflection of women in the Qur'an does not entail any segregation prohibiting intermingling between women and men, but in Saudi society, women are only allowed to live a private life without mixing in any way with men other than their relatives. The use of different entrances and limitations regarding the sharing of common eating places hinder women from studying subjects related to engineering and law as well as technologically oriented subjects [3].

Many practices in Saudi society, such as women not being allowed to work, travel, study and marry without first gaining authorisation from a male guardian are laws that do not have any backing from the Qur'an [27]. This indicates that the role that woman guardian play in Saudi society is fundamental and transferred from male to another. For example, when women do not have any male relatives, they do not become responsible for themselves but they become the responsibility of the judge [16]. This practice of capability should be reduced while other types must be improved like the independence of women, if it is identified as a threat to individuals in the family who feel thwarted by gender equality, or males with political power who identify gender equality as an endeavour that could render them vulnerable to power inferiority [3]. The teachings of the Holy Book and their portrayal of women regard both genders equally in many aspects of general life, however, women are not allowed to drive or travel alone in Saudi society even if it is not prohibited by the Qur'an [27].

\section{Conclusion}

Saudi society is a unique mix between religion and culture, which poses difficulties for the government over education for women. The position of women in this society is complicated and they have to face a lot of barriers to get an education as they live under male authority all the time. This situation is against their status in the Holy Book (Qur'an) which offers capabilities that benefit women, such as their right to make their own decisions about which things are suitable for them in Islamic societies, but the structure of these societies gives men the power to control these capabilities and change them to serve their needs. Therefore, the status of women in such societies needs to be enhanced by treating them with more respect and making sure their rights as human are respected as such ways would improve their chance of completing their education.

\section{References}

[1] Ahmadi, F., (2006), Islamic Feminism in Iran, 'Feminism in a New Islamic Context,' Journal of Feminist Studies in Religion, 1: pp. 34-53.

[2] Al Lily, A. E. A., (2011). On line and under veil: Technologyfacilitated communication and Saudi female experience within academia. Technology in Society, 33 (1-2): pp. 119-127.

[3] Al-Fahad, F.N., (2010), The Learners' Satisfaction Toward Online E-Learning Implemented In The College Of Applied Studies And Community Service, King Saud University, Saudi Arabia: Can ELearning Replace the Conventional System of Education?, Turkish Online Journal of Distance Education, 11 (2): pp. 61-73.

[4] BBC, (2011), Women in Saudi Arabia to vote and run in elections [online], BBC News Middle East, 25-09-2011, available at: http://www.bbc.co.uk/news/world-us-canada-15052030, [Accessed: 20/09/2014].

[5] BBC, (2013), Saudi Arabia's king appoints women to Shura Council [online], BBC News Middle East, 11th January 2013, available at: http://www.bbc.co.uk/news/world-middle-east20986428, [Accessed: 19/10/2014].

[6] Brym, R. J. and Lie, J., (2010), Sociology: Your Compass for a New World, 2nd ed, Cengage Learning, USA.

[7] Coleman I., (2011), Women, Islam, and the Push for Reform in the Muslim World [online], Solution Journal, 2 (2): pp. 42-51, Available at: http://www.thesolutionsjournal.com/node/900, [Accessed: 26/11/2014].

[8] Cordesman, A. H., (2003), Saudi Arabia Enters the Twenty-First Century: The Political, Foreign Policy, Economic, and Energy Dimensions. Westport, CT: Praeger. 
[9] Deaver, S., (1980), The contemporary Saudi women. In: Bourguignon E, ed. A world of women: anthropological studies of women in the societies of the World. New York: Praeger.

[10] Doumato, E., (2000), Getting God's Ear: Women, Islam, and Healing in Saudi Arabia and the Gulf. New York: Columbia University Press.

[11] Doumato, E., (2002), Women and Work in Saudi Arabia: How flexible are Islamic margins? Middle East Journal, 52 (2), Spring, 582.

[12] Doumato, E., (2010), Saudi Arabia, In Sanja Kelly and Julia Breslin, eds., Women's Rights in the Middle East and North Africa, New York, NY: Freedom House; Lanham, MD: Rowman \& Littlefield, 2010', pp. 2-30.

[13] Evans, M., (2011), doing gender: Gender and women's studies in the twenty first centuries, Women's Studies International Forum, 34: pp. 603-610.

[14] Faiza S., (2005), Saudi women recall a day of driving, [Online], The Christian Science Monitor, [Online] available at: http://www.csmonitor.com/2005/1207/p06s02-wome.html, [Accessed: 15/11/2014]

[15] Fierke, K. M. and Jørgensen, K. E. (eds.)., (2001), Constructing International Relations: the Next Generation, Armonk: M. E. Sharpe.

[16] Hamdan, A., (2005), Women and education in Saudi Arabia: Challenges and achievements. International Education Journal, 6 (1), 42-64.

[17] Hurley et al., (2008), Futures studies and Feminism, FUTURES, 40: pp. 388-407.

[18] Kaufman, M., (1999), Men, Feminism, and Men’s Contradictory Experiences of Power, London, UK: SAGE Publications.

[19] Kendall, B., (2006), Saudi Arabia's unseen reform, [online], BBC News, Middle East, 26th April 2006, Available at: http://news.bbc.co.uk/2/hi/programmes/from_our_own_correspon dent/4952046.stm. [Accessed; 17/10/2014].
[20] Leslie, L. (2011) Saudi Feminism doesn’t Mirror Western Ideas. Muslim Voice, [Online] Available at: $<$ http://muslimvoices.org/saudi-feminism-mirror-western-ideas/> [Accessed: 23/11/2014]

[21] Lord, M., Greiter, A. and Tursunovic, Z., (2012), Feminist Theory, [online], available at www.soc.iastate.edu/sapp/Feminist.ppt, [Accessed: 10/11/2014].

[22] Margot, B., (2011), From Islamic Feminism to a Muslim Holistic Feminism, IDS Bulletin, 42 (1): pp. 78-87

[23] Mehran, G., (2003), The Paradox of tradition and modernity in female education in the Islamic republic of Iran, Comparative Education Review, 47 (3): pp. 269-286.

[24] Metz, H. C., (1992), Saudi Arabia: A Country Study, Washington: GPO for the Library of Congress, [Online] Available at: $<$ http://countrystudies.us/saudi-arabia/> [Accessed: 23/10/2014].

[25] Olaniyi, S. S., (2006), E-Learning Technology: The Nigeria Experience, A paper presented at Shape the Change XXIII FIG Congress, October 8-13, Munich Germany.

[26] Prokop, M., (2003), Saudi Arabia: The politics of education, International Affairs, 79(1): pp. 77-89.

[27] Roy, D., (1992), Saudi Arabian education: development policy. Middle Eastern Studies, 28: pp. 477-508.

[28] Saudi Gazette, (2008), Business: Kingdom's e-learning industry to reach \$125 million this year. The Saudi Gazette, 26th April.

[29] Sechzer, J., (2004), Islam and Woman: Where Tradition Meets Modernity: History and Interpretations of Islamic Women's Status,' Sex Roles, 51 (5/6): pp. 263-272

[30] Sen, A., (2000), Social Exclusion: Concept, Application, and Scrutiny: Asian Development Bank.

[31] Wajcman, J., (1991), Feminism Confronts Technology, Cambridge: Polity Press.

[32] Wiseman, A.W., Sadaawi, A. \& Alromi, A.H., (2008), Educational Indicators and National Development in Saudi Arabia, paper presented at the 3rd IEA International Research Conference 18-20 September, Taipei City, Taiwan. 